Authors' Accepted Manuscript. This paper will appear in a special issue of Victorian Periodicals Review in December 2018.

\title{
Credit, Copyright, and the Circulation of Scientific Knowledge: The Royal Society in the Long Nineteenth Century
}

\section{AILEEN FYFE, JULIE MCDOUGALL-WATERS, AND NOAH MOXHAM}

In 1803, Charles Hutton, the mathematician, author, and fellow of the Royal Society, sent a note to its president, Sir Joseph Banks, announcing "his intention to undertake the care of arranging and printing a new abridgement of the Philos[ophical] Transactions." ${ }^{1}$ The Philosophical Transactions had been founded in 1665 and had been under the direct financial and editorial control of the Royal Society since $1752 .^{2}$ Chunky quarto parts of varying lengths appeared roughly at six-month intervals, carrying extensive (and often illustrated) accounts of new scientific observations, discoveries, and experiments. It was the most prestigious research periodical in the English-speaking world. By 1803, its back issues contained many significant contributions to natural knowledge (as well as much that had been disproved or superseded). Hutton proposed to select, abridge, and index the contents of the past 135 years, "trusting that the President and Council would please to countenance this undertaking."3

This was a lot to take on trust, in two respects. First, Hutton proposed to exploit publications subsidised by the Royal Society for his own gain, and second, his relationship with Banks had not been cordial for twenty years. ${ }^{4}$ It is unsurprising, therefore, that the initial response to Hutton's 1803 note was non-committal; only a record of its communication was noted. Yet Hutton and his associates proceeded with the venture and in 1809 applied for and received permission to dedicate the first volume of the Transactions to the "President, Council and Fellows of the Royal Society." ${ }^{5}$ Regardless of what personal animosity Banks still felt or what material loss the Royal Society had feared, no one tried to prevent the abridgement from going ahead. And there was material loss to be anticipated: Hutton's 
Authors' Accepted Manuscript. This paper will appear in a special issue of Victorian Periodicals Review in December 2018. project was intended to supersede an earlier abridgement by John Lowthorp, which had found sufficient customers to justify five editions and three successive expansions between 1703 and 1749. Later accounts of Hutton's life published in the town of his birth suggest that he received $£ 6,000$ for his work on the abridgement. ${ }^{6}$

Whether the Royal Society had any legal power under the copyright statutes in force at the beginning of the nineteenth century to prevent an undertaking of this kind is doubtful. Periodicals were not yet explicitly included in copyright legislation in the United Kingdom; the act of abridgement could be represented as the creation of a new work; and most (though not all) of the material Hutton proposed to use was old enough that it would have been out of copyright anyway. Yet Hutton asked permission from the Royal Society. This is a strong indication that the society had a moral and customary claim to the Transactions which had little or nothing to do with copyright legislation.

In this paper, we will consider the Royal Society's attitudes towards the copying, reprinting, and reuse of material from the Transactions during the nineteenth century. In addition to the biannual part issues and bound annual volumes, the contents of the Transactions circulated in print in a variety of other ways: the private circulation of authors' separate copies of papers (i.e. offprints); the reissuing of papers in authors' collected works; the incorporation of material into authors' subsequent books (and sometimes, as with Hutton, books by third parties); and through the reports and excerpts (and sometimes full reprints) of particular pieces that had appeared in the general scientific periodical literature in the United Kingdom (and in translation elsewhere).

In the eighteenth century, the Royal Society's two key concerns were, first, that what appeared in the Transactions should not have already appeared elsewhere and, second, that it would promote the circulation of natural knowledge (both through its own actions in distributing the Transactions and its generous attitude to reprinting and reuse). In the 
Authors' Accepted Manuscript. This paper will appear in a special issue of Victorian Periodicals Review in December 2018.

nineteenth century, the growth of the scientific press-particularly of commercially oriented monthly (and later weekly) journals carrying news and short reports of scientific developments - meant that opportunities for the "literary replication" of material from the Transactions vastly increased. ${ }^{7}$ So, too, did the possibility of the Transactions being "scooped" as editors sought to report Royal Society meetings in a timely fashion and as scientific researchers became increasingly interested in rapidly publishing their new results. At the same time, the society was subsidising the publication and distribution of the Transactions to an ever-increasing extent. The inclusion of special provisions for periodicals in the 1842 Copyright Act potentially gave it the opportunity to claim copyright protection. ${ }^{8}$

But the Royal Society's attitude to reprinting and reuse was rarely informed by finances. It did not register the Transactions (or its more frequently published Proceedings) at Stationers' Hall, either before or after 1842. And there are very few examples of the society refusing permission to reprint material from the Transactions or of any attempt to pursue those who had reprinted content without permission. Nonetheless, pressure from the expanding commercial scientific press led the society to develop strategies for managing and even encouraging the reprinting of material from the Transactions. It always insisted on its own right to credit as the first site of publication, though by the end of the century, the question of what it had first published (the bare bones of the discovery or a fully detailed account) became more complicated.

Our key argument is that the Royal Society's relations with scientific authors, editors, and publishers were governed by custom and courtesy, not by copyright. This was partly due to the society's relative lack of interest in profits and partly due to the fact that its attitudes toward reprinting had been formed in a different age. The society's continuing ability to set the terms for the publication and reuse of its material was a remarkable achievement amidst 
Authors' Accepted Manuscript. This paper will appear in a special issue of Victorian Periodicals Review in December 2018. rapid changes in the scientific profession and the periodical press during the nineteenth century.

\section{Historical Formation}

The Royal Society's attitudes toward copyright and circulation were formed long before the nineteenth-century copyright acts. The Philosophical Transactions pre-dated the 1710 Statute of Anne and had, in any case, stood outside the earlier licensing regime. Thanks to the licensing privileges granted to the Royal Society in its 1662-63 charters, the early editors could publish the Transactions under the authority of the Royal Society without registering the title with the Stationers' Company. ${ }^{9}$ This makes the question of who had right to its literary property all but impossible to settle, even hypothetically. ${ }^{10}$ The official line was that the current Transactions was the responsibility and property of the incumbent editor, rather than the society, but the question of who retained rights in the back issues remained ambiguous.

After 1752, the situation was somewhat clarified when the Royal Society's definitively assumed editorial and financial control of the Transactions. The periodical was henceforth to be run "for the sole use and benefit" of the Royal Society, with the institution paying for the cost of publication, retaining ownership of the entire edition of each volume, and receiving the income on any copies sold through the retail trade. ${ }^{11}$ In 1776 , the society introduced a new statute indicating that the "original copy" of every paper read at a society meeting would "be considered as the property of the Society." 12 The physical manuscripts were deposited in the society's library, where they could be consulted by fellows and approved guests, and the society appears to have understood that its common-law ownership of the "copy" included the right to exclusive publication. ${ }^{13}$ The society's governing council would gradually come to interpret the right more broadly still as the authority to make prepublication changes as they saw fit. ${ }^{14}$ 
Authors' Accepted Manuscript. This paper will appear in a special issue of Victorian Periodicals Review in December 2018.

The Royal Society's responses to reprinting and reuse were regulated through custom and courtesy rather than by established legal forms. Its moral claim to ownership of the Transactions material was widely recognised and respected within Britain, both before and after 1752. When John Lowthorp and later two rival publishers planned to create abridgements of the accumulated back-run of Transactions, in 1702 and 1720 respectively, they felt obliged to seek permission from the society rather than from contributors or past editors. ${ }^{15}$ The fact that the society granted permission without any expectation or demand for financial compensation is striking, especially in the case of the rival abridgements of the 1720 s, by which time the commercial success of Lowthorp's earlier abridgement was apparent. The eighteenth-century reprints and abridgements established a precedent for the society's response to Charles Hutton in 1803, and more generally, they established the framework that would inform the society's dealings with editors and publishers during the nineteenth century. The society wished to encourage the circulation of knowledge and thus expected no payment from those who reprinted or reused the Transactions papers; however, it did expect symbolic payment in the form of attribution and acknowledgement and had the long-established moral authority and codes of conduct to enforce it.

\section{Enabling Re-Use}

One way that the Royal Society fulfilled its commitment to the wide circulation of the Transactions was through its generous arrangements for the gratis distribution of the printed copies, both as bound volumes and as separate copies of individual papers. All fellows living in Britain could claim copies of the latest parts of Transactions, and authors received varying numbers of off-prints. In addition, in 1838, over sixty institutions (mostly in Britain and Europe) received free copies of the society's periodicals, and by 1908 this list had grown to over 400 institutions worldwide. This extensive free circulation — which far outstripped actual 
Authors' Accepted Manuscript. This paper will appear in a special issue of Victorian Periodicals Review in December 2018.

sales-demonstrated that the Royal Society's attitude toward potential profits was vastly different than that of commercially oriented periodical publishers. ${ }^{16}$

The Royal Society also encouraged and enabled the reuse of its material. This did not simply mean granting permission to authors who wished to republish parts or all of their papers elsewhere (this was routinely granted); the society also freely gave permission to authors and their publishers to make use of the engraved copper plates (and, later, lithographic stones) that produced the illustrations for their papers. Thus, in 1838 when Michael Faraday sought "leave to reprint . . my Experimental researches in Electricity," he also sought permission to use the plates for his illustrations, writing, "I would also beg the favour of the loan of the plates to the various papers as it is my wish to make the work as cheap as possible." ${ }^{17}$ The comparative anatomist Richard Owen likewise promised in 1850 that he would "superintend the careful printing of the impressions, and [ensure] that the stones be restored to their original conditions," if he were allowed to borrow them. ${ }^{18}$

The value of the Royal Society's willingness to facilitate the reproduction and reuse of images can be gauged by the ubiquity of the requests: by the 1870 s, the minutes of almost every council meeting included at least one request and often several. By this time, increasing numbers of the images in the society's periodicals were being printed from wood engravings, and the introduction of electrotyping created new means of reproducing such images. The standard response was to grant the supplicant permission "to have electrotype copies [made], at his own expense." By the 1880s, this phrasing was routinely condensed to "on the usual conditions." 19

It was most often the author who sought permission to use the plates or stones for reprinting illustrations, but permission was also granted to bona fide third parties: for instance, a publisher preparing a new edition of the works of the late John Hunter or a widow preparing a republication of her husband's works on porpoises. ${ }^{20}$ In 1877 , the publisher 
Authors' Accepted Manuscript. This paper will appear in a special issue of

Victorian Periodicals Review in December 2018.

Taylor \& Francis sought permission to use Faraday's plates, some of them now nearly forty years old, for a (posthumous) facsimile reprint of the Experimental Researches. ${ }^{21}$

The pages of the Transactions do not appear to have been stereotyped or electrotyped in the nineteenth century; thus, even though images could be reprinted from the Royal Society's plates or stones, there was no equivalent for the text. Authors usually asked permission to have the text typeset by their printer, as Faraday had done. But some authors instead found ways to be creative with the printed pages of their separate copies. The Royal Society had been allowing authors to purchase extra copies of their papers for private circulation among friends, colleagues, and correspondents since at least the $1780 \mathrm{~s} .{ }^{22} \mathrm{By}$ the start of the nineteenth century, the society had begun to provide a certain number of free "separates" to authors, while still allowing for the purchase of additional copies. ${ }^{23}$

Men of science often had separate copies of published articles, either their own papers or those received from other scholars, bound for easier storage and consultation, thereby producing unique volumes for personal use. Authors could potentially use their allowance of separate copies to create multiple sets of their collected works for wider circulation. In the 1860s and 1870s, Richard Owen circulated volumes of his collected papers on fossil remains to "public libraries of cities and towns in Australia and Tasmania." 24 His activities drew a reprimand from the council in 1877 , which assumed he had caused additional copies of his images of Australian fossils to be printed without permission. Owen explained that the plate pages were actually from his separate copies (hence the quarto format of the volumes, and why only 100 copies had been produced). The council ignored Owen's offer of financial compensation for any damage he might have caused to the "property of the Society." 25 Instead, it directed the secretary to convey "regret" that the Society and the Transactions had been inadequately acknowledged: in particular, "that the Society's mark at the head of the plates should have been obliterated without express permission." ${ }^{26}$ When the proper 
Authors' Accepted Manuscript. This paper will appear in a special issue of Victorian Periodicals Review in December 2018.

attribution was lacking, the society clearly saw reuse less as a threat to income than as a threat to reputation.

Limiting the number of free "separates" offered to authors (variously, either fifty or 100 copies) controlled the society's costs. But after the episode with Owen's plates, the council introduced a new restriction on the number of additional copies available for purchase (150 copies), and clarified its guidance as to the acceptable uses of such "separates." This guidance reiterated that all separate copies (whether free or purchased) were "for gratuitous distribution only"; however, it also implicitly encouraged Owen's actions by allowing authors to seek permission for other uses and by explicitly allowing them to request the renumbering of pages and images for separate publication. ${ }^{27}$

The appropriate use of separate copies remained a difficult question into the early twentieth century. In 1905, the Royal Society received a circular letter from the Liverpool Institute of Tropical Research asking for the terms on which it could supply "from 500 to 2000 extra copies of any communications made to the Royal Society by members of the Institute's Scientific Staff." 28 The institute was one of several which saw off-prints as a relatively cheap way to create volumes showcasing the research of their staff, and the scale of the request makes clear that these were not just sets for internal use. This prompted yet another resolution limiting the number of separate copies but retaining the possibility for exceptions "in special cases." ${ }^{29}$ Such cases continued to arise: thus, in 1910, an author was allowed to purchase 500 additional copies "for binding with the archives of the Claybury Asylum Pathological Laboratory."30

The reuse we have discussed so far took place after research articles had been accepted for publication and printed in the Transactions (or, later, in the Proceedings). At this point, the Royal Society was supportive of most efforts to circulate knowledge more widely, especially if they were non-commercial in nature. As the Owen case demonstrated, 
Authors' Accepted Manuscript. This paper will appear in a special issue of Victorian Periodicals Review in December 2018. the society insisted on attribution because it was concerned about reputational credit rather than the loss of potential income.

\section{Maintaining Exclusivity before Publication}

The aspect of reporting and reuse that most concerned the Royal Society was maintaining its exclusive right to be the first site of publication for submitted works. To understand why this was so, it is essential to appreciate the relationship between the society's meetings and its periodicals. ${ }^{31}$ From 1752 until the end of the nineteenth century, papers were submitted to the society for reading at meetings and were only subsequently considered for publication in the Transactions. The meetings were not open to the general public, but fellows could bring guests. There was thus a real possibility that the key facts of the paper-if not its full details - could circulate through scholarly networks well ahead of formal publication. This was exacerbated by the practice of allowing authors to acquire separate copies as soon as they were ready, which was often well ahead of the appearance of the biannual issues of the Transactions. With news leaking out from the meetings and separate copies circulating privately, it was entirely possible for a journal editor accidentally or intentionally to report or reprint material from Royal Society meetings before the publication of the Transactions.

The growth of the scientific periodical press made this a particular problem. Between the 1790 s and the 1820 s, several monthly magazines of science were launched as commercial ventures. These were the first self-identified scientific "journals," which were very different from the slow and stately Transactions (and its kin at other learned societies). ${ }^{32}$ Their regular and frequent periodicity was promoted to readers as a means of learning the latest scientific goings-on and to authors as an opportunity to spread news of their discoveries faster and more easily than through learned societies. Reports of society meetings and summaries or extracts of recent scientific papers were exactly the sort of material that helped these new journals find readers. 
Authors' Accepted Manuscript. This paper will appear in a special issue of Victorian Periodicals Review in December 2018.

In 1802, William Nicholson, proprietor of the commercial monthly Journal of Natural Philosophy, wrote to the president of the Royal Society to ask permission to reprint content from separate copies. ${ }^{33} \mathrm{He}$ felt this would be a service to his readers and to the world of science, but Joseph Banks refused him point-blank. The society was willing to allow reprinting after the papers were published, but for Banks, "publication" meant when the volume of Transactions was "publish[ed] for Sale." ${ }^{34}$ Banks threatened that the society might become stricter about allowing post-publication reprinting "if any further liberties are taken." ${ }^{35} \mathrm{He}$ later wrote that he and Nicholson differed "materially in opinion relative to the proper mode in which journalists ought to use the unexampled indulgences given to them by the Royal Society of republishing the Philosophical Transactions." ${ }^{\text {"3 }}$ Nicholson's efforts at persuasion imploded shortly afterwards, when Banks discovered that Nicholson had accidentally reprinted two as-yet-unpublished Transactions papers. He had been acting on advice on the probable time of publication of the Transactions, but it was unfortunately delayed.

This episode reveals the tension between the Royal Society's perception of its common-law intellectual property (including the right to publish such material as and when it wished) and the growing demand for the rapid publication of scientific knowledge. Nicholson acknowledged that the "property of the Copies" belonged to the society, but he complained of being at a disadvantage compared to "foreign philosophers," whose journals often printed reports and translations based on separate copies received from British correspondents. ${ }^{37}$ If Nicholson (and other "journalists within the realm") could treat the issue of separate copies as "publication," then they would be legitimately able to report, excerpt, or comment on research papers from that moment on. ${ }^{38}$

The immediate consequence of Banks's exchange with Nicholson was to delay the wider reporting and reuse of Royal Society material for an even longer period. The council 
Authors' Accepted Manuscript. This paper will appear in a special issue of Victorian Periodicals Review in December 2018.

decided to add an explicit request on the covers of separate copies, asking those who received them, "to use their endeavour to prevent them from being reprinted till one Month after the publication of the Part of the Volume of the Philos: Transactions in which they are inserted." 39

By insisting that the Transactions was not on public sale until the issue of the volumes and by insisting on a one-month monopoly after publication, Banks sought to keep Transactions material exclusive to the Royal Society for as long as possible. This ensured that the publication of the Transactions was not superfluous or a waste of the society's limited funds. It was not until the 1870s that the society's leadership appears to have recognised that insisting on a long period of exclusivity could be seen as hampering the circulation of knowledge and that enabling earlier reporting and reprinting (with appropriate attribution) might enhance the society's reputation.

By the late nineteenth century, the Royal Society's relationship with the scientific periodical press had been transformed due to changes in its own procedures and by changes in the press. The creation in late 1830 of a new periodical, known as Proceedings, gave the society a new way to publicly mark its claim to the material presented at its meetings. ${ }^{40}$ Issued approximately monthly during the society session (roughly November to June), the Proceedings carried abstracts of the papers from each meeting, ensuring that their key points appeared in print more quickly than the Transactions could manage. The Proceedings largely came to replace the reports of meetings of the society that had been carried in the commercial journals. By the end of the century, the Proceedings increasingly carried full versions of short papers, as well as abstracts of longer papers that would later appear in the Transactions. The Proceedings, rather than the Transactions, became the focus of reporting, reprinting, and excerpting in the wider scientific press. 
Authors' Accepted Manuscript. This paper will appear in a special issue of Victorian Periodicals Review in December 2018.

The appearance of weekly news magazines such as Chemical News (1859-1926) and Nature (1869-present) helped change attitudes toward timeliness among scientific researchers who wanted to forge their reputations through print. ${ }^{41}$ Chemical News and Nature (and the quarterly Popular Science Review) were the titles that most frequently requested permission to reuse images from Royal Society periodicals. Their editors, William Crookes and Norman Lockyer, were themselves fellows of the society and were thus well aware of the latest discoveries that could potentially be reported and the society's willingness to allow the reuse of its plates. Nature did not have the page space to reprint full Transactions papers, but it reported papers presented to the society (after an account in Proceedings had appeared) and reprinted some of the shorter papers from Proceedings, including many of Lockyer's own contributions. ${ }^{42}$ The shift in the society’s publication regime from biannual to roughly monthly meant that the tensions between editors' weekly schedules and the society's desire to claim first-publication rights, along with subsequent attribution, were less fraught than they might otherwise have been.

Furthermore, in 1875, the Royal Society tacitly abandoned Joseph Banks's insistence that separate copies did not count as "publication." In response to concerns about the accessibility of Transactions papers, the society began to place a small number of separate copies on public sale through a London bookseller. ${ }^{43}$ These were the full versions, rather than the abstracts that had already appeared in Proceedings, which were available some weeks or months ahead of the formal publication in the Transactions. The sales of these separate papers were extremely modest (usually fewer than ten copies), but they were now clearly available to the public and thus were a legitimate source for reporting and excerpting.

A final shift came in the 1890s when the Royal Society's procedures for meetings and publications were amended. ${ }^{44}$ Presenting to a meeting ceased to be a necessary first step in the publication process, thus reducing the risk of new discoveries being reported ahead of 
Authors' Accepted Manuscript. This paper will appear in a special issue of Victorian Periodicals Review in December 2018.

publication. Yet, at the same time, the society was sufficiently confident in the robustness of the codes of conduct that had been agreed with the scientific news editors over the years that it began to send separate copies of papers directly to selected editors as soon as they were available. ${ }^{45}$ In 1898 , the council also decided to allow representatives of the press to attend meetings. ${ }^{46}$ This suggests a shift from Banks's focus on maintaining exclusivity to a desire to promote the circulation of scientific papers in whose reception the society had an interest.

\section{Reporting and Circulating Science}

As Will Slauter discusses elsewhere in this issue, during the later nineteenth century, certain daily newspapers lobbied for a change to copyright law so that news could be protected. (News was explicitly not protected under the Berne Convention of 1886.) Newspaper proprietors sought a short period of guaranteed exclusivity to delay the moment at which other newspapers could report news that had been originally gathered by another and thereby to protect their commercial investment in news-gathering. The question of a copyright for news was discussed by an 1898 select committee of the House of Lords, as part of a consideration of how copyright applied to derivative uses such as abridgements, translations, and adaptations. Most of the witnesses were broadly inclined towards a more restrictive definition of what would constitute a "fair and moderate" use of extracts or quotation. ${ }^{47}$ It therefore provides an intriguing contrast with the Royal Society's liberal approach to the reporting, reprinting, and reuse of its material. The key is the society's non-commercial motivation for publishing scientific research. ${ }^{48}$

There were many parliamentary committees and investigations into copyright during the nineteenth century, but we have found no evidence that the Royal Society directly engaged with any of them. ${ }^{49}$ It certainly did give advice and evidence on other matters to parliamentary committees and government departments, sometimes on behalf of the wider community of scientific societies. Its absence from the debates on copyright speaks to the 
Authors' Accepted Manuscript. This paper will appear in a special issue of Victorian Periodicals Review in December 2018. distance between learned society publishing and the commercially focused book trade during this period. Nonetheless, those who drafted copyright legislation were aware of scientific literature as a genre with a distinctive perspective on the balance between public good and financial benefit. Thus, in 1898 members of the Lords committee used the recent discovery of the first noble gas, argon, as a means to think through the appropriateness of the proposed protection for news-reporting. ${ }^{50}$ Perhaps not coincidentally, one of the discoverers of argon was the Royal Society secretary and M.P., Lord Rayleigh. ${ }^{51}$

Much of the debate turned on whether the fact of discovery should be protected, along with the words in which it was expressed. Could another newspaper report a cricket score from Australia or a revolution in Chile if they used different words from the original newspaper report? C. F. Moberly Bell, editor of the Times, argued that the facts themselvesnot just the phrasing of the report — should be exclusive to the newspaper that had made the investment in overseas correspondents and long-distance telegraphy. ${ }^{52}$ The Lords committee members were concerned that the period of exclusivity sought by the Times would be detrimental to the circulation of knowledge. Committee members used scientific examples to interrogate their witnesses, asking, "Was not everybody who described Argon, and how Argon was obtained infringing the copyright of Lord Rayleigh and Professor Ramsay in the document in which they communicated that discovery to the world?"53

Where did the limit lie between commenting on a discovery and infringing copyright by re-stating it? Several of the newspaper witnesses claimed not to see the analogy between cricket and argon, but one legal witness accepted it and thus found himself arguing that the very fact of the discovery of argon belonged to Rayleigh and the Transactions and should not be more widely reported: 
Authors' Accepted Manuscript. This paper will appear in a special issue of Victorian Periodicals Review in December 2018.

Lords: "But you say that if an astronomer has discovered a new star, or a chemist a new element, and published that fact to the world, nobody may repeat that fact without infringement of copyright?"

Witness: "Just as if a poet has discovered a new poem.",54

The Lords clearly felt that such tight restrictions on the circulation of scientific knowledge were counter to the public interest. Through questioning, they brought the witness to admit a distinction based on commercial value: "In the case of Argon it could do no harm to Lord Rayleigh to say that he had discovered a new gas, Argon; but in the case of pirating a telegram from Santiago, it would do a great deal of harm to the paper." 55

From the Royal Society's perspective, there was no commercial threat to the Transactions in the scientific periodical press (or even the newspapers) reporting the discovery of a new gas. This was partly because the Transactions was supported through subsidy and not by sales income but also because the reporting served the needs of different audiences from those who consulted the full articles published in the Transactions. Reading the Times's five-paragraph report of Ramsay's lecture on the discovery of argon gas would be insufficient for researchers in the field who needed the full details. ${ }^{56}$ Even if they had read the newspaper report, researchers would still need to consult either the twenty-three-page "abstract" in the Proceedings or wait till later in the year for the fifty-four-page Transactions article. The newspaper report would nevertheless bring the names of Rayleigh, Ramsay, argon, and the Royal Society to a much wider audience. Rather than bringing commercial harm, such reporting enhanced the society's reputation.

Back in the early nineteenth century, Joseph Banks had assumed that a pre-existing report of a new discovery would make the publication of that discovery in the Transactions worthless. By the late nineteenth century, his successors were far less worried so long as the Royal Society was credited and the reports or extracts were not so extensive as to vitiate the 
Authors' Accepted Manuscript. This paper will appear in a special issue of Victorian Periodicals Review in December 2018.

full publication of the article in Transactions. Thus, in the 1850s and 1860s, rather than censuring the physicist John Tyndall for giving lectures on research that was forthcoming with the Royal Society, the society's officers helped him schedule dates for his presentation to fit into his lecture schedule at the Royal Institution. ${ }^{57}$

The tension between reaching alternative audiences and potentially undermining the prestige of the Transactions was made explicit in 1891 when the self-taught electrician (and former telegraph operator) Oliver Heaviside submitted his first paper to the Royal Society. Heaviside had been proposed as a society fellow in 1890, and just days after his formal election in June 1891, he submitted a paper on the forces, stresses, and fluxes of energy in electromagnetic fields. ${ }^{58}$ While this was his first encounter with Royal Society publishing, Heaviside already had many publications to his name in such journals as the Philosophical Magazine, the Electrician, and the Journal of the Society of Telegraph Engineers. Indeed, at the same time he was submitting his full paper to the Royal Society, he had prepared a shorter version for the Electrician. He was surprised, therefore, when he received the proof copy of his abstract for Proceedings along with note indicating that he was "forbidden to publish any fuller account of my paper without permission." 59 As he wrote to the society's secretary, Lord Rayleigh: "It happens, in my ignorance of this rule, that I was going to publish this week or next some parts of 'Electromagnetic Theory' (in The Electrician) which overlaps the full paper 'On the Forces, etc.', and it certainly, (in the overlapping parts) goes a long way beyond the abstract for the Proceedings." ${ }^{60}$ Heaviside enclosed the proof of his proposed article for the Electrician so that the society could be compare the two contributions.

Heaviside's abstract was read at the Royal Society's next weekly meeting. The Society needed to decide whether the proposed Electrician article "embodies so much of the substance of the full paper as to make the latter's publication in 'Philosophical Transactions of the Royal Society' or 'Proceedings of the Royal Society' unadvisable." ${ }^{\prime \prime}$ A fellow with 
Authors' Accepted Manuscript. This paper will appear in a special issue of Victorian Periodicals Review in December 2018. relevant expertise was asked to report urgently. Within a week, he replied that the Electrician article was indeed a "much fuller account and contains much more of the substance of the paper than the abstract" but that the "full paper would have to be referred to by any one wishing to study the matter seriously." ${ }^{262}$ Heaviside had offered to drop the Electrician article, but the referee did not feel that its publication would "render later publication by the Society useless." ${ }^{63}$ In this case, Heaviside's prior publication habits had led him unwittingly to endanger his publication opportunity with the Royal Society. But as with Tyndall's lectures, the society ultimately decided that the wider circulation of knowledge was beneficial as long as the society's claim to prior publication was acknowledged.

It is significant that Heaviside, like Tyndall, was seeking to circulate his findings in a shortened form among "[readers] who cannot go into details" rather than to specialists in the field ${ }^{64}$ In 1908, when a different author sought permission in 1908 to reprint his entire paper in the Chemical Trades Journal shortly after it had been published in the Transactions, the society was unsympathetic: "It is for sale to the public at a reasonable price as a separate paper. They are therefore surprised that such an application should be made now," just two weeks after publication. ${ }^{65}$ This was not a re-packaging of the text for a more general reader even though the author probably hoped to widen the audience for his research. The society felt that a summary or report should have directed readers to the original paper. It is notable that the society did not object to the application based on copyright infringement but on its customary rules for granting permission.

\section{Conclusion}

The Royal Society made a point of not publishing anything second hand and was thus unlikely to infringe other people's copyright. Such violations or oversights had been penalised since the late eighteenth century. ${ }^{66}$ The society's reputation as a publisher depended on its being the preferred venue for accomplished men of science to publish their full, 
Authors' Accepted Manuscript. This paper will appear in a special issue of Victorian Periodicals Review in December 2018.

extended results. The Transactions and the Proceedings occupied different niches in the ecosystem of scientific publishing that were distinct from those occupied by scientific weeklies such as Nature. They published at a length and level of detail and illustration that the commercial periodicals could not imitate, which meant that their position as the "version of record" was secure enough to sustain a generous approach to reporting and reuse aimed at broader audiences.

It appears to have been the growing use of "preliminary notes" that ultimately shifted the relationship between the prestigious learned society periodicals and the faster, cheaper commercial journals. During the late nineteenth and early twentieth centuries, researchers in highly competitive fields such as physics saw the attraction of claiming priority through brief, advance announcements of new results. A rapid-publication periodical like Nature was an attractive venue for such notes, though Proceedings could also be used in that way. Such notes were usually followed up with a detailed report in a learned society periodical that could offer the necessary space for elaboration. Thus, the Proceedings and the Transactions retained their role as the version of record but would come to lose their traditional role as the venue for the first announcement of the discovery.

The authors and fellows of the Royal Society saw publishing as a means of sharing knowledge with the scholarly community and as a means of generating individual and especially institutional credit and reputation. This put learned society publishing out of kilter with contemporary trends in copyright reform, which placed increasing emphasis on protecting commercial interests rather than promoting the common good. The ubiquity of the requests it received for reprinting text or reusing illustrative plates, stones and electrotypes is proof of how widely understood the Royal Society's customary code of conduct had become. Even though the society did not register its periodicals at Stationers' Hall, scientific journal editors and authors (along with their heirs and publishers) all appear to have understood that 
Authors' Accepted Manuscript. This paper will appear in a special issue of Victorian Periodicals Review in December 2018.

they should seek permission for reuse and that such permission would normally be granted.

This code of conduct was never, so far as we have discovered, enforced by legal action; instead, it operated through custom, tradition, and moral suasion.

Aileen Fyfe, University of St Andrews

Noah Moxham, University of Kent

Julie McDougall-Waters, Independent

\section{NOTES}

${ }^{1}$ Royal Society Council Minutes (Original), volume 8 (hereafter RS CMO/8), March 31, 1803.

${ }^{2}$ Fyfe, McDougall-Waters, and Moxham, "350 Years of Scientific Periodicals,” 229-31.

${ }^{3}$ Royal Society Council Minutes (Original), volume 8 (hereafter RS CMO/8), March 31, 1803.

${ }^{4}$ Hutton and Banks had been on opposite sides during the "dissensions" at the Royal Society in 1783. See Hall, All Scientists Now, chapter 1, and Wardhaugh, "Charles Hutton and the Dissensions."

${ }^{5}$ RS CMO/8, April 29, 1809.

${ }^{6}$ Mackenzie, Descriptive and Historical Account, 1:559.

${ }^{7}$ Fyfe, "Journals and Periodicals," pp. 389-91. For "literary replication," see Secord, Victorian Sensation, 126.

${ }^{8}$ For background on the provisions of the 1842 act, see Elena Cooper's contribution to this special issue of Victorian Periodicals Review.

${ }^{9}$ See Moxham, “Uses of Licensing," forthcoming; Johns, Nature of the Book, pp. 492-98.

${ }^{10}$ See Rivington, "Early Printers to the Royal Society."

${ }^{11}$ RS CMO/4, February 15, 1751/2. 
Authors' Accepted Manuscript. This paper will appear in a special issue of Victorian Periodicals Review in December 2018.

${ }^{12}$ The statutes of 1776 are described in Record of the Royal Society, 168.

${ }^{13}$ Feather, "From Rights in Copies to Copyright," 197-9.

${ }^{14}$ Joseph Planta to Joseph Banks, April 5, 1783, in Chambers, Scientific Correspondence, 3:62-63. In practice, authors were often, but not always, consulted about such changes.

${ }^{15}$ Lowthorp, Philosophical Transactions Abridged. RS CMO/3, January 19 \& 26, February 2, March 23, 1721.

${ }^{16}$ Fyfe, "Royal Society and the Free Circulation of Knowledge," (forthcoming).

${ }^{17}$ Michael Faraday to S. H. Christie (Royal Society secretary), November 14, 1838, in James, Correspondence, vol. 2, letter 1117; and RS Council Minutes (Printed), vol. 1 [hereafter RS CMP/01], November 29, 1838. This became Faraday's Experimental Researches in Electricity (London: Taylor, 1839).

${ }^{18}$ Owen to the Royal Society, recorded in RS CMP/02, October 24, 1850. Owen did not, in the end, re-use these images of fossil reptiles.

${ }^{19}$ See, for example, RS CMP/04, February 16, 1871, and RS CMP/05, November 30, 1880. ${ }^{20}$ See RS CMP/02 May 22, 1851 (regarding Hunter's works) and RS CMP/05, February 21, 1878 (regarding Dr. Sibson's work on porpoise respiration).

${ }^{21}$ RS CMP/04, April 19, 1877, This edition was printed by Taylor \& Francis for the antiquarian bookseller Bernard Quaritch.

${ }^{22}$ The earliest mention we have found of "separate copies" is from 1786. See Charles Blagden to Erasmus Darwin, Blagden Papers, RS CB/2/34, September 14, 1786. This letter suggests that authors could deal directly with the printer for up to 100 copies.

${ }^{23}$ This is apparent from Council Minutes, RS CMO/08, July 15, 1802.

${ }^{24}$ All of these quotations are from RS CMP/05, February 21, 1878 (citing correspondence from December 20, 1877).

${ }^{25}$ RS CMP/05, February 21, 1878 (citing correspondence from December 20, 1877). 
Authors' Accepted Manuscript. This paper will appear in a special issue of Victorian Periodicals Review in December 2018.

${ }^{26}$ RS CMP/05, February 21, 1878.

${ }^{27}$ RS CMP/05, March 21, 1878.

${ }^{28}$ RS CMP/09, October 26, 1905.

${ }^{29}$ RS CMP/09, February 15 \& 22, 1906.

${ }^{30}$ RS CMP/10, December 8, 1910 (regarding a paper by Frederick Mott on sleeping sickness).

${ }^{31}$ For a fuller discussion, see Fyfe and Moxham, "Making Public ahead of Print."

${ }^{32}$ See Topham, "Anthologizing the Book of Nature," and Watts, "We Want No Authors."

${ }^{33}$ This episode is discussed in Watts, "We Want No Authors," passim.

${ }^{34}$ Draft letter of Joseph Banks to William Nicholson, March 12, 1802, published in

Chambers, Scientific Correspondence, 5:148-49.

${ }^{35}$ Ibid.

${ }^{36}$ Unpublished draft letter, first name Banks to first name Nicholson, April 24, 1802, British

Library Add. MS 33981, f. 26. Quoted in Watts, "We Want No Authors," 417.

${ }^{37}$ William Nicholson to Joseph Banks, March 12, 1802, published in Chambers, Scientific

Correspondence, 5:147-48.

${ }^{38}$ Ibid.

${ }^{39}$ RS CMO/08, July 15, 1802.

${ }^{40}$ For background on the decision to issue the Proceedings, see RS CMO/11, December 16, 1830.

${ }^{41}$ See Brock, William Crookes, 54, and 'Chemical News', 33; Baldwin, Making “Nature”, 24, 28, 35; and Mussell, Science, Time and Space, cx-cxv.

${ }^{42}$ For an example report of a paper from a meeting, see "Researches upon the specific volume of liquids"; for a reprint of a full paper from Proceedings, see "Terrestrial Helium (?).” 
Authors' Accepted Manuscript. This paper will appear in a special issue of Victorian Periodicals Review in December 2018.

${ }^{43}$ RS CMP/04, June 17, 1875, The bookseller was Nicholas Trübner.

${ }^{44}$ Fyfe and Moxham, "Making Public ahead of Print,", 364, 372.

${ }^{45}$ RS CMP/07, November 3, 1892.

${ }^{46}$ Ibid. In 1893, a journalist from a daily newspaper had been excluded. See RS CMP/07, April 27, 1893.

${ }^{47}$ Report from the Select Committee, pp. 8-10, 36-7, 100-101

${ }^{48}$ See Fyfe, "Journals, Learned Societies and Money."

${ }^{49}$ The first evidence we have found of the Royal Society being involved in copyright reform is from the mid-twentieth century, when it gave evidence to the 1951-52 Board of Trade Copyright Committee, Cmd. 8662.

${ }^{50}$ Report from the Select Committee, 236-9

${ }^{51}$ Argon was announced at a Royal Society meeting held at the University of London on January 31, 1895. See Rayleigh and Ramsay's two articles titled “Argon, a New Constituent of the Atmosphere" published in the Philosophical Transactions and the Proceedings of the Royal Society.

${ }^{52}$ Report from the Select Committee, 52. This passage focuses on C. F. Moberly Bell's evidence.

${ }^{53}$ Ibid., 236 (T. E. Scrutton's evidence). The analogy with chemistry was also raised in questioning Bell and Murray.

${ }^{54}$ Ibid., 237

${ }^{55}$ Ibid.

56 “The New Gas," 6.

${ }^{57}$ For more details, see Fyfe and Moxham, "Making Public ahead of Print." 
Authors' Accepted Manuscript. This paper will appear in a special issue of Victorian Periodicals Review in December 2018.

${ }^{58}$ Heaviside, "Forces, Stresses, and Fluxes [abstract]." The full paper was Heaviside, "On the Forces, Stresses, and Fluxes of Energy in the Electromagnetic Field," in Series A of Philosophical Transactions.

${ }^{59}$ Oliver Heaviside to Lord Rayleigh (secretary), RS Miscellaneous Manuscripts, MM/17/109, June 17, 1891.

${ }^{60}$ Ibid.

${ }^{61}$ Herbert Rix to Professor John Henry Poynting, RS NLB/5/466, June 19, 1891.

${ }^{62}$ J. H. Poynting to the secretaries of the Royal Society, RS MM/17/92, June 241891.

${ }^{63}$ Ibid.

${ }^{64}$ Ibid.

${ }^{65}$ J. Larmor (secretary) to J. E. Petavel, RS NLB/37/248, February 22, 1908.

${ }^{66}$ Chambers, Scientific Correspondence, 2:178-79, October 16, 1783. In this letter, Charles Blagden expressed his concern that a paper by the Glasgow astronomer Patrick Wilson had been anticipated and critiqued in print by Jérôme Lalande.

\section{BIBLIOGRAPHY}

Anon., 'Researches upon the Specific Volumes of Liquids', Nature 121875 17-20

—_.'Terrestrial Helium?', Nature 521895 7-8.

Baldwin, Melinda. Making "Nature”: The History of a Scientific Journal. Chicago: University of Chicago Press, 2015.

Brock, William H. William Crookes (1832-1919) and the Commercialization of Science. Aldershot: Ashgate, 2008. .'The Chemical News, 1859-1932', Bulletin for the History of Chemistry 12 (1992): $30-4$

Chambers, Neil. The Scientific Correspondence of Sir Joseph Banks, 1765-1820. 6 vols. London: Pickering \& Chatto, 2007. 
Authors' Accepted Manuscript. This paper will appear in a special issue of Victorian Periodicals Review in December 2018.

Feather, John. "From Rights in Copies to Copyright: The Recognition of Authors' Rights in English Law and Practice in the Sixteenth and Seventeenth Centuries." In The Construction of Authorship: Textual Appropriation in Law and Literature, edited by Martha Woodmansee and Peter Jaszi, 191-209. Durham: Duke University Press, 1994.

Fyfe, Aileen. "Journals and Periodicals." In A Companion to the History of Science, edited by Bernard Lightman, 387-99. New York: Wiley, 2016.

—_. "Journals, Learned Societies and Money: Philosophical Transactions, ca. 17501900." Notes and Records of the Royal Society 69, no. 3 (2015): 277-99.

_ . "The Royal Society and the Free Circulation of Knowledge." In Constellations of Knowledge, edited by Martin Paul Eve and Jonathan Gray. Cambridge: Cambridge University Press, forthcoming.

Fyfe, Aileen, and Noah Moxham. "Making Public ahead of Print: Meetings and Publications at the Royal Society, 1752-1892." Notes and Records of the Royal Society 70, no. 4 (2016): 361-79.

Fyfe, Aileen, Julie McDougall-Waters, and Noah Moxham. “350 Years of Scientific Periodicals." Notes and Records of the Royal Society 69, no. 3 (2015): 227-39.

Hall, Marie Boas. All Scientists Now: The Royal Society in the Nineteenth Century. Cambridge: Cambridge University Press, 2002.

Heaviside, Oliver. “On the Forces, Stresses, and Fluxes of Energy in the Electromagnetic Field." Philosophical Transactions A, 183 (1892): 423-80.

—. "On the Forces, Stresses, and Fluxes of Energy in the Electromagnetic Field." Proceedings of the Royal Society of London 50, no. 302-7 (1891): 126-29.

James, Frank A. J. L. The Correspondence of Michael Faraday. 6 vols. London: Institution of Electrical Engineers, 1991-2012. 
Authors' Accepted Manuscript. This paper will appear in a special issue of Victorian Periodicals Review in December 2018.

Johns, Adrian. The Nature of the Book: Print and Knowledge in the Making. Chicago: University of Chicago Press, 1998.

Lowthorp, John. The Philosophical Transactions Abridged, and Disposed under General Heads. 3 vols. London: Thomas Bennet, Robert Knaplock, Richard Wilkin, 1703-8. Mackenzie, Eneas. A Descriptive and Historical Account of the Town and County of Newcastle-upon-Tyne. 2 vols. Newcastle-upon-Tyne: Mackenzie and Dent, 1827. Moxham, Noah. "The Uses of Licensing: Publishing Strategy and the Imprimatur at the Early Royal Society.” In Institutionalising Sciences in Early Modern Europe, edited by Mordechai Feingold and Giulia Giannini. Leiden: Brill, forthcoming.

Mussell, James. Science, Time and Space in the Late Nineteenth-Century Periodical Press. Aldershot: Ashgate, 2007.

Rayleigh, Lord, and William Ramsay. "Argon, a New Constituent of the Atmosphere.” Philosophical Transactions A, no. 186 (1895): 1.

—. "Argon, a New Constituent of the Atmosphere." Proceedings of the Royal Society, no. 57 (1895): 265-87.87-241.

The Record of the Royal Society of London. 3rd ed. London: Royal Society, 1912.

Report from the Select Committee of the House of Lords on the Coypright Bill (H.L.). London: HMSO, 1898.

Rivington, Charles A. "Early Printers to the Royal Society, 1663-1708." Notes and Records of the Royal Society 39, no. 1 (1984): 1-27.

Secord, James A. Victorian Sensation: The Extraordinary Publication, Reception and Secret Authorship of Vestiges of the Natural History of Creation. Chicago: University of Chicago Press, 2000.

The Times of London, 'The New Gas', February 1 1895: 6 
Authors' Accepted Manuscript. This paper will appear in a special issue of Victorian Periodicals Review in December 2018.

Topham, Jonathan R. "Anthologizing the Book of Nature: The Circulation of Knowledge and the Origins of the Scientific Journal in Late Georgian Britain.” In The Circulation of Knowledge between Britain, India, and China, edited by Bernard Lightman and Gordon McOuat, 119-52. Boston: Brill, 2013.

Wardhaugh, Benjamin Sutherland. 'Charles Hutton and the 'Dissensions' of 1783-84:

Scientific Networking and Its Failures." Notes and Records of the Royal Society 71, no. 1 (2017): 41-59.

Watts, Iain. “'We Want No Authors': William Nicholson and the Contested Role of the Scientific Journal in Britain, 1797-1813.” British Journal for the History of Science 47, no. 3 (2014): 397-419. 